\title{
Digital methodology for improving efficiency of enterprises at the regional agro-industrial complex
}

\author{
O.V. Vlasova ${ }^{1, *}$, E.B. Kalinichenko ${ }^{2}$, and $A . A$. Rebrov $^{1}$ \\ 1 Project management and foreign economic activity in the AIC chair, Saratov State Agrarian \\ University named after N.I. Vavilov, 410012, 1, Teatralnaya sq., Saratov, Russian Federation \\ ${ }^{2}$ Foreign languages and culture speech chair, Saratov State Agrarian University named after N.I. \\ Vavilov, 410012, 1, Teatralnaya sq., Saratov, Russian Federation
}

\begin{abstract}
The article examines the current mechanism of state management of the regional agroindustrial complex, studies the business processes of entrepreneurship in the agro-industrial complex of Russia and suggests methods to increase their activity. A digital methodology for making and optimizing management decisions is proposed, based on a multi-criteria assessment of an operating enterprise, district, region as a system that allows optimizing their activities.
\end{abstract}

\section{Introduction}

The relevance of this study lies in the need to introduce an effective mechanism for managing the agroindustrial complex as a single system consisting of both sectoral and regional subsystems. The rapid development of agriculture in Russia and the world as a whole requires the use of progressive, more dynamic, innovative and digital methods for assessing, monitoring and managing its development.

\section{Methods}

For a multi-criteria assessment of the development of the regional agro-industrial complex, the method of hierarchical decomposition of the problem of optimal management of the potential of agroindustrial enterprises is applied. Visual interpretation of the hierarchical model makes it possible to evaluate the criteria necessary to solve the management problem at both the regional and district levels of agribusiness management. Methods have been applied to improve the management mechanism of the agro-industrial complex enterprise:

* abstract-logical;

* monographic and economic-statistical;

* computer optimization.

The study used materials from Rosstat and the Ministry of Agriculture of the Russian Federation.

* Corresponding author: vlasik_vik@mail.ru 


\section{Results}

As a result of the conducted research, it was revealed that in order to increase the activity of business processes of entrepreneurship in the agro-industrial complex, it is necessary to have no bureaucracy, freedom of search, rapid testing of innovations, that is, innovative activity, as well as timely and informed adoption of managerial, including design decisions.

One of the tools to increase the activity of business processes is the implementation of innovative projects. In relation to the agro-industrial complex, the definition is formulated: an innovative project is an economic document that defines a specific transition to the development and development (or only development) of innovations in agro-industrial production, agreed on resources and deadlines.

To introduce innovations based on innovative and investment projects, it is necessary to assess the potential of the enterprise, region, industry using a systematic approach, identify alternative options for implementing strategies and choose the most effective ones, that is, to carry out all stages of managerial decision-making.

The scheme of functioning of the management decision-making information system, which allows its transfer to a digital platform, is presented (Fig.1).

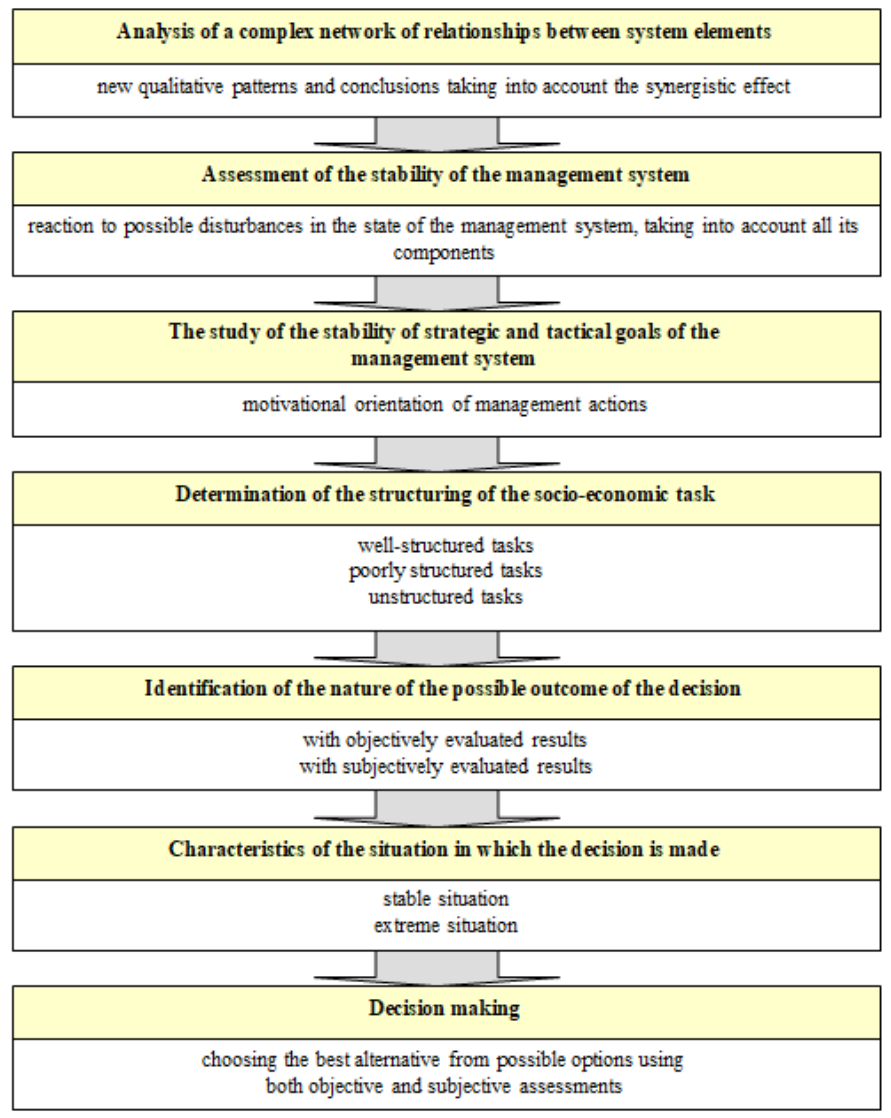

Fig. 1. The scheme of functioning of the management decision-making information system [1].

The assessment of the current mechanism of state management of enterprises of the regional agroindustrial complex in modern conditions, including the organizational and 
administrative mechanism, mechanisms of innovative development, support of social directions, financial and budgetary support (Fig.2).

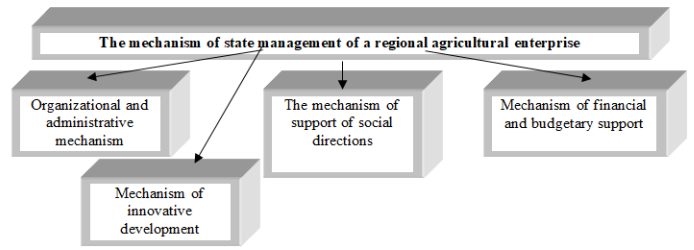

Fig. 2. Management mechanisms of the regional agro-industrial complex.

The mechanism of state management of a regional agricultural enterprise is constantly being improved. Public administration and regulation are provided by various methods, which are ways of influencing market actors. As the economy develops, the range of applied methods of state influence is constantly expanding [2].

Currently, measures aimed at the development of domestic agricultural production and maintaining a high level of food security are being implemented at the state and regional levels [3].

Thus, within the framework of the national projects currently being implemented in Russia, the following state programs operate:

* the State program of the Russian Federation "Integrated development of rural areas";

* the state program of effective involvement in the turnover of agricultural lands and the development of the reclamation complex of the Russian Federation;

* state program for the development of agriculture;

* development of the fisheries complex;

* federal scientific and technical program for the development of agriculture for 2017 2025 .

In order to ensure the sustainable development of the agro-industrial complex of the Saratov region, which is one of the leading agricultural regions of the country, the investment Strategy of the Saratov region provides for the solution of the following main tasks [4]:

* stimulating the growth of production of the main types of agricultural products;

* improving the competitiveness of Saratov products in the domestic and foreign markets;

* stimulation of technical and technological modernization of production, innovative development of the agro-industrial complex, development of biotechnology;

* support of small forms of management and cooperation in rural areas;

* increasing the level of profitability in agriculture to ensure its sustainable development;

* support for the development of the infrastructure of the agri-food market;

* improving the efficiency of regulation of agricultural products, raw materials and food markets;

* creation of conditions for the effective use of agricultural land;

* development of agricultural land reclamation;

* development of food production in order to increase the level of provision of the population of the region with domestic products;

* development of competitive, export-oriented industrial production.

State support of the agro-industrial complex by the end of 2020 was provided to the enterprises of the agro-industrial complex of the Saratov region in the amount of more than 2.7 billion rubles (Table 1). 
Table 1. Implementation of the state program for the development of agriculture of the Saratov region in 2020.

\begin{tabular}{|l|c|c|c|c|}
\hline \multicolumn{1}{|c|}{$\begin{array}{c}\text { Total amount of } \\
\text { financial security }\end{array}$} & Plan & $\begin{array}{c}\text { Actual } \\
\text { execution }\end{array}$ & $\begin{array}{c}\text { Cash } \\
\text { execution }\end{array}$ & $\begin{array}{c}\text { \% } \\
\text { execution }\end{array}$ \\
\hline total, including & 2760530,1 & 2760130,4 & 2663441,4 & 100,0 \\
\hline regional budget & 706757,6 & 706427,3 & 706427,3 & 100,0 \\
\hline federal budget & 1957014,2 & 1957014,1 & 1957014,1 & 100,0 \\
\hline local budgets & 2139,9 & 2070,6 & 0,0 & 96,8 \\
\hline $\begin{array}{l}\text { extra- } \\
\text { budgetary sources }\end{array}$ & 94618,4 & 94618,4 & 0,0 & 100,0 \\
\hline
\end{tabular}

The regional project "Export of agricultural products" is being implemented at the regional level. In the Saratov region, its implementation is carried out within the framework of the National Project "International Cooperation and Export" and provides for an increase in the production of export-oriented agricultural crops [5].

One of the enterprises actively implementing this project in terms of the production and sale of grain, including for export, is JSC "Decabrist", located in the Ershovsky district of the Saratov region.

A study of the best practices of this agricultural enterprise specializing in the production of grain and leguminous crops has been conducted. (tables 2, 3, 4).

Table 2. Provision of fixed assets of JSC "Decabrist".

\begin{tabular}{|c|c|c|c|c|}
\hline Indicator & $\begin{array}{l}2018 \\
\text { year }\end{array}$ & $\begin{array}{l}2019 \\
\text { year }\end{array}$ & $\begin{array}{l}2020 \\
\text { year }\end{array}$ & $\begin{array}{c}\text { Deviation } \\
(+,-) 2020-2018 \\
\text { years }\end{array}$ \\
\hline $\begin{array}{l}\text { The cost of fixed assets, } \\
\text { thousand rubles }\end{array}$ & 303616 & 492658 & 506427 & +202811 \\
\hline $\begin{array}{l}\text { Energy capacity, hp } \\
\text { Number of employees, people.. } \\
\text { Area of agricultural land, ha } \\
\text { Stock availability of the farm, thousand rubles per } \\
100 \text { hectares of agricultural land } \\
\text { Labor capital ratio, thousand rubles. } \\
\text { Energy supply of the farm, hp per } 100 \text { hectares of } \\
\text { agricultural land } \\
\text { The power of labor, hp. }\end{array}$ & 14215 & 14215 & 14215 & 0 \\
\hline $\begin{array}{l}\text { Number of employees, people.. } \\
\text { Area of agricultural land, ha } \\
\text { Stock availability of the farm, thousand rubles per } \\
100 \text { hectares of agricultural land } \\
\text { Labor capital ratio, thousand rubles. } \\
\text { Energy supply of the farm, hp per } 100 \text { hectares of } \\
\text { agricultural land } \\
\text { The power of labor, hp. }\end{array}$ & 110 & 106 & 112 & +2 \\
\hline $\begin{array}{l}\text { Area of agricultural land, ha } \\
\text { Stock availability of the farm, thousand rubles per } \\
100 \text { hectares of agricultural land } \\
\text { Labor capital ratio, thousand rubles. } \\
\text { Energy supply of the farm, hp per } 100 \text { hectares of } \\
\text { agricultural land } \\
\text { The power of labor, hp. }\end{array}$ & 18459 & 18598 & 18645 & +186 \\
\hline
\end{tabular}




\begin{tabular}{|c|c|c|c|c|}
\hline $\begin{array}{l}\text { Stock availability of the farm, thousand rubles per } \\
100 \text { hectares of agricultural land } \\
\text { Labor capital ratio, thousand rubles. } \\
\text { Energy supply of the farm, hp per } 100 \text { hectares of } \\
\text { agricultural land } \\
\text { The power of labor, hp. }\end{array}$ & 16,45 & 26,49 & 27,16 & $+10,7$ \\
\hline $\begin{array}{l}\text { Labor capital ratio, thousand rubles. } \\
\text { Energy supply of the farm, hp per } 100 \text { hectares of } \\
\text { agricultural land } \\
\text { The power of labor, hp. }\end{array}$ & 2760,1 & 4647,7 & 4521,7 & $+1761,6$ \\
\hline $\begin{array}{l}\text { Energy supply of the farm, hp per } 100 \text { hectares of } \\
\text { agricultural land } \\
\text { The power of labor, hp. }\end{array}$ & 77,0 & 76,4 & 76,2 & $-0,8$ \\
\hline $\begin{array}{l}\text { The power of labour, hp } \\
\text { Labor capital ratio, thousand rubles. } \\
\text { Energy supply of the farm, hp per } 100 \text { hectares of } \\
\text { agricultural land } \\
\text { The power of labor, hp. } \\
\text { Labor capital ratio, thousand rubles. } \\
\text { Energy supply of the farm, hp per } 100 \text { hectares of } \\
\text { agricultural land } \\
\text { The power of labor, hp. }\end{array}$ & 129,2 & 134,1 & 126,9 & $-2,3$ \\
\hline
\end{tabular}

Table 3. Efficiency of use of fixed assets of JSC "Decabrist".

\begin{tabular}{|l|c|c|c|c|}
\hline \multicolumn{1}{|c|}{ Indicator } & $\begin{array}{c}\mathbf{2 0 1 8} \\
\text { year }\end{array}$ & $\begin{array}{c}\mathbf{2 0 1 9} \\
\text { year }\end{array}$ & $\begin{array}{c}\mathbf{2 0 2 0} \\
\text { year }\end{array}$ & $\begin{array}{c}\text { Deviation } \\
\text { (+,-) 2020- } \\
\mathbf{2 0 1 8 y e a r s .}\end{array}$ \\
\hline The cost of fixed assets, thousand rubles. & 303616 & 492658 & 506427 & +202811 \\
\hline Gross agricultural output, thousand rubles. & 141838 & 203517 & 475121 & +333283 \\
\hline $\begin{array}{l}\text { Profit, thousand rubles. Return on funds, rub. } \\
\text { Fund capacity, rub. Fund profitability, \% }\end{array}$ & 14625 & 21896 & 122549 & +107924 \\
\hline $\begin{array}{l}\text { Profit, thousand rubles. Return on funds, rub. } \\
\text { Fund capacity, rub. } \\
\text { Fund profitability, \% }\end{array}$ & 0,47 & 0,41 & 0,94 & $+0,47$ \\
\hline $\begin{array}{l}\text { Fund capacity, rub. Fund capacity, rub. } \\
\text { Fund profitability, \% }\end{array}$ & 2,14 & 2,42 & 1,07 & $-1,07$ \\
\hline Fund profitability,\% & 4,8 & 4,4 & 24,2 & $+19,4$ \\
\hline
\end{tabular}

Table 4. Efficiency of economic activity of JSC "Decabrist".

\begin{tabular}{|l|c|c|c|c|}
\hline \multirow{2}{*}{ Indicator } & \multicolumn{3}{|c|}{ Years } & $\mathbf{2 0 2 0}$ y. to 2018 \\
\cline { 2 - 4 } & $\mathbf{2 0 1 8}$ & $\mathbf{2 0 1 9}$ & $\mathbf{2 0 2 0}$ & $\mathbf{y} \%$ \\
\hline $\begin{array}{l}\text { Revenue from the sale of products, } \\
\text { thousand rubles. }\end{array}$ & 137279 & 192888 & 473532 & In 3,4 times \\
\hline
\end{tabular}




\begin{tabular}{|l|c|c|c|c|}
\hline Total cost of products sold, thousand rubles. & 122654 & 170992 & 352983 & 287,8 \\
\hline Profit (+), loss (-), thousand rubles. & 14625 & 21896 & 122549 & in 8,4 times \\
\hline Level of profitability, \% & $+11,9$ & $+12,8$ & $+34,8$ & in2,9 times \\
\hline Level of return on sales, \% & $+10,6$ & $+11,4$ & $+25,9$ & in 2,4 times \\
\hline Balance sheet profit, thousand rubles. & 17485 & 20392 & 140164 & in 8,0 times \\
\hline
\end{tabular}

The study showed that, despite the presence of all the components necessary for the innovative development of the enterprise, an optimal decision-making system based on expert assessments is needed.

In the proposed methodology, the decomposition of the management problem for JSC "Decabrist" is presented in the form of a multi-level hierarchy (Fig. 3).



Fig.3. Visual interpretation of the hierarchical model in assessing the development potential of JSC "Decabrist" as an economic system operating in the external environment [1].

Calculations according to the proposed methodology were carried out for the period 2017-2019. The director of the enterprise acted as an expert to determine the weight coefficients. At the same time, the priorities of his evaluative statements were determined and the values of the weighting coefficients were calculated on their basis (Table 5).

Table 5. The final results of computer calculations of rating estimates of the activities of JSC "Decabrist" when changing the priorities of production activities.

\begin{tabular}{|c|c|c|c|}
\hline Year & $\mathbf{t}_{\mathbf{0}}=\mathbf{2 0 1 7} \boldsymbol{\Gamma}$. & $\mathbf{t}_{\mathbf{1}}=\mathbf{2 0 1 8} \mathbf{\Gamma}$. & $\mathbf{t}_{\mathbf{2}}=\mathbf{2 0 1 9} \mathbf{\Gamma} \mathbf{.}$ \\
\hline $\begin{array}{c}\text { Indicator rating } \\
\text { asessment }\end{array}$ & 1,00 & 1,421 & 1,162 \\
\hline$\%$ & 100 & 142,1 & 116,2 \\
\hline
\end{tabular}

As a result, the company's management decided to change the structure of the acreage for the 2020 harvest. The results of the effectiveness of management decisions are presented in Tables 2, 3, 4 .

\section{Discussion}

The digital methodology of multi-criteria assessment proposed in the paper can be used to assess the development potential of agro-industrial enterprises, as well as widely used at the level of districts and regions as economic systems. This methodology will allow the 
management of enterprises to plan and optimize their activities, and regional and municipal government bodies to constantly monitor the development potential of agro-industrial enterprises, take preventive measures to develop and implement departmental programs for their infrastructure support. Evaluation criteria and weighting factors of subjective assessments of experts, specialists and managers may vary.

\section{Conclusion}

The results of the study were to identify the effectiveness of the proposed multi-criteria assessment methodology on the example of a specific agricultural enterprise. Its application made it possible in 2020 to optimize the structure of the acreage of the investigated enterprise of JSC "dEcembrist", increasing the sowing of spring crops at the expense of winter crops. As a result of management decisions made on the basis of expert assessments, the company's revenue increased 3.4 times, profit 8.4 times, profitability increased 2.9 times.

\section{References}

1. O.V. Vlasova, Agricultural Scientific Journal, 20, 2 (2006)

2. O.V. Vlasova, E.Yu. Serban, Agrarian Scientific Journal, 9 (2015)

3. I.L. Vorotnikov, K.P. Kolotyrin, A.V. Romanov, A.V. Nayanov, M.S. Gutuev, Utopia y Praxis Latinoamericana, 25 (2020)

4. S. Baskakov, E. Rudoy, I. Vorotnikov, I. Sukhanova, M.I. Glukhova, International Journal of Economics and Business Administration, 8, 1 (2020)

5. I.L. Vorotnikov, I.F. Sukhanova, M.Y. Lyavina, M.I. Glukhova, K.A. Petrov, Entrepreneurship and Sustainability Issues, 6, 4 (2019)

6. D. Abol-Fotouh, M. A. Hassan, H. Shokry, A. Roig, M. S. Azab, A. E. Kashyout, Scientific Reports, 10, 1(2020)

7. C. Amor, L. Marchão, M. S. Lucas, J. A. Peres, Water (Switzerland),11, 2 (2019)

8. R. R. C. Bastos, A. P. da Luz Corrêa, P. T. S. da Luz, G. N. da Rocha Filho, J. R. Zamian, L. R. V. da Conceição, Energy Conversion and Management, 205 (2020)

9. D. Carrillo-Nieves, M. J. Rostro Alanís, R. de la Cruz Quiroz, H. A. Ruiz, H. M. Iqbal, R. Parra-Saldívar, Renewable and Sustainable Energy Reviews, 102 (2019)

10. A. M. Girelli, M. L. Astolfi, F. R. Scuto, Chemosphere, 244 (2020)

11. R. S. Singh, N. Kaur, J. F. Kennedy, Carbohydrate Polymers, 217 (2019)

12. M. Wakkel, B. Khiari, F. Zagrouba, Journal of the Taiwan Institute of Chemical Engineers, 96 (2019) 